\title{
Die Afrikaanse Geskiedbeskouing
}

$\mathrm{Na}$ aanleiding van my voordrag voor die vierde kongres ter bevordering van die wysbegeerte wat in Februarie in Pretoria gehou is, het die redaksie my genader oor bogenoemde onderwerp. Voor die kongres het ek gepraat oor die Afrikaanse geskiedenisbeeld, wat natuurlik iets anders is as die geskiedbeskouing van die Afrikaner. Maar tussen die twee dinge is daar 'n samehang. ' $n$ Beeld is juis die resultaat van 'n skou in of oor die verlede en dit suggereer ' $n$ bepaalde visie op die afgelope gebeurtenisse. Dis die resultaat van afstand neem van die verlede en van besinning oor wat met 'n volk gebeur het. Hoe beskou die volk die afloop of verloop in die verlede en wat stel hy in vooruitsig vir die toekoms? 'n Geskiedbeskouing bevat dus ook iets van die toekoms. 'n Mens kan nie oor die verlede nadink as jy nie die toekoms in jou visie betrek nie. As 'n mens vra of iemand 'n geskiedbeskouing het, vra jy eintlik of hy 'n fundamentele insig in die verlede besit, gebaseer op 'n oorsig oor die geskiedenis in sy verloop én eenheid, op grond waarvan hy kan weet waarheen hy gaan en wáár hy staan in die tye. Dit impliseer die hele geskiedenis. Vir die Afrikaner wat tot onlangs nog diep in isolasie verkeer het, moet onder die geskiedenis verstaan word, die geskiedenis van die Afrikanervolk; dit was sy werklikeid en die wêreld waarin hy hom tot diep in die 20ste eeu begewe het.

Dit is nie maklik om vas te stel presies hoé die Afrikanervolk in die verlede én tans oor sy geskiedenis dink nie.
Dan is die vraag of ' $n$ mens die uitinge van één indiwiduele Afrikaner kan neem as geldig vir die res? Eers as 'n mens verskillende beskouinge oor die geskiedenis vergelyk het, kan jy tot 'n gevolgtrekking kom. Dan is die moeilikheid ook dat 'n Afrikaner nie doelbewus gaan sit en gedagtes i.v.m. sy beskouing oor die geskiedenis gaan neerskryf het nie. Jy kan alleen insig daarin kry as jy 'n dokument lees waarin hy hom feitlik onbewus oor sy verlede uitgelaat het, sodat 'n mens eintlik indirek toegang tot sy beskouinge kry.

Nou is die vraag: Wanneer het die Afrikanervolk vir die eerste keer 'n beskouing oor sy eie verlede begin ontwikkel? Dit is ook nie maklik om vas te stel nie. Uit geskrifte is dit vir my duidelik dat 'n bewuste nadenke oor sy geskiedens gevolg het toe hy in die uiterste nasionale nood verkeer het, $j a$, in 'n tyd toe hy 'n oorsig oor die volk as geheel begin kry het. Die eerste spore daarvan kan 'n mens vind in die voortdurende herhaling in die mond van die Voortrekkers van die woorde „Wij hebben onze Moederland verlaten". Hier dus die beginpunt van hulle historiese herinneringe en van die nadink oor wát met hulle gebeur en wát hulle gedoen het. Dit het egter nog nie die Afrikaanse volk as geheel in die prentjie gebring nie. Eers rondom die jare 1874-1881 vind ons dat die Kapenare die Republikeinse Noorde in hulle lotgevalle betrek en omgekeerd dat die Republikeinse Noorde die Afrikaners van die Koloniale Suide in hulle lotgevalle betrek. Dit beteken die vorming 
van 'n geslote beeld waarin die hele Afrikaanse volk plek gekry het. Eers toé kan 'n mens van 'n nadink oor hulle eie lotgevalle praat. Dit was eers toe hulle die Groot Trek oorbrug het, en ontdek het dat Suid-Afrika één is, en huisves, één is. Dit het onder die druk van die Britse imperiale dade i.v.m. die Anneksasie van Basoetoland, die diamantvelde en die Transvaal gevolg. Rondom die jare 1877-1881 ontstaan 'n Afrikaanse nasionalisme wat voorheen nie daar was nie. En as byproduk van hierdie nasionalisme ontwaak die historiese bewussyn, wat eintlik die verantwoording was van wát met hulle gebeur het, wié hulle was en wát hulle taak moet wees.

Hoe het die Afrikaners hulle eie geskiedenis beleef en beskou? Onder indruk van die eie hede, sou hulle hul na die verlede wend en daarin ' $n$ verklaring soek vir die wese en gees vir die Afrikaanse volk. Hulle sou die begin of oorsprong nagaan. en daarvandaan lyne na hul eie tyd met sy probleme deurtrek.

Ten eerste: Vir hulle oorsprong is God as 'n verklaringsbasis aangeneem. As daar ooit 'n sterk lyn deur die denke van die Afrikaner deurloop, dan is dit die basiese gedagte dat God verskillende elemente uit Holland, Nederland en Duitsland hier bymekaar gebring het met 'n bepaalde doel. Hy het hulle koms bewerk en hulle hier laat saamsmelt tot nasie. Die voornuers is in die lig van geloofsvlugtelinge gesien en die aandeel van die Hugenote is besonder sterk benadruk. God het hulle hierheen gestuur as die „sout" wat die wilde elemente in die Kaap moes kom suiwer. Juis rondom die jare 1874-1881 word die Hugenote ontdek - en wel in die sin van dankbaarheid teenoor God wat dit in Sy wysheid goed gedink het om hulle hierheen te "stuur". Veral ds. S. J. du Toit het die gedagte na vore gebring. Die gevoel dat die Boere rondom 1881 self vervolgdes was, het die idee sterker laat posvat dat hulle van ,arme geloofsvlugtelinge" afstam. Hulle is self deur God hier ,geplant", vir hulle is daar ,plek gemaak" en die volk kon sy wortels laat inskiet.

En dan: God het die Afrikanervolk wat hy uitverkies het om na die Suiderland te kom, 'n opdrag gegee - hy het 'n taak wat hy moet uitvoer. In sy geskiedenisbeskouing kom hierdie gedagte net so sterk uit, nl. die gedagte van geroepenheid en van uitverkorenheid. Hy het homself tussen barbare en die natuur gesien en omring van vyande: en tog - God het gered, beskerm, bewerk. Hy het die volk self gelei, hulle gedagtes van vryheid in die hart gelê, hulle betugtig met aanvalle van die Bantoe en die Britte - alles met die doel om hulle te louter. President Kruger het hierdie gedagtes sterk beklemtoon in sy Paardekraaltoesprake. $\mathrm{Ja}$, vir hom was die Afrikaanse volk 'n verbondsvolk. Het die Trekkers dan nie 'n gelofte aan God afgelê nie? En moe hulle dan nie dié gelofte hou nie? En hulle besondere taak? Die Voortrekkers al het gestel dat hulle deur God in die wildernis gebring is om die Evangelie aan die Heidene te verkondig, d.i. om die lig van die beskawing en Christendom in die duistere binneland in te dra. Dit was vir hulle geloof. Hierdie gedagte kom dikwels gedurende die 19de eeu tot uiting. 
Wat was die grondslag hiervoor? Die Ou Testament, dié Boek van die Boerevolk, en 'n Boek wat nie weinig daartoe bygedra het om die Afrikaner te laat ontwikkel tot wat hy geword het nie. In Israel van ouds het hulle 'n parallel vir hulle eie bestaan en omstan dighede gehad. En hoe dikwels het hulle hul nie met die volk van Israel vergelyk nie? Hulle taak was so eenders, hulle roeping deur God so gelyk en hulle lotgevalle tussen heidense volkere so sprekend dieselfde. Ook hulle het 'n gelofte aan God gedoen soos die Jode soms geloftes gedoen het. Ook hulle het tekens van die verbondenheid met God daargestel soos bv. die Geloftekerk en die klipstapeling op Paardekraal. Ek sal talle dokumente om hierdie bewerings te staaf, kan aanhaal. Vir die Boere van die 19de eeu was God die God van die geskiedenis. $\mathrm{Hy}$ het alles oorsien en beoordeel en $\mathrm{Hy}$ sou regspreek tussen die Britse vervolgers en die "verdrukte" Afrikaners. Van sy troon het $\mathrm{Hy}$ op die verloop van sake neergestaar en die verloop self gerig. Hy self sou reg laat geskied aan verontregtes en $\mathrm{Hy}$ sou op Sy tyd die waarheid aan die lig bring. Met die Eerste Vryheidsoorlog was dit vir hulle of God self die verloop van sake gelei, en die offisiere aangevoer het. Die Tweede Vryheidsoorlog weer, is gesien as die loutering van die Afrikaanse volk deur God self. Hy het maar net die ,vyand" gebruik as instrument in Sy hand om die volk te tugtig en na Hom te lei. Vandag nog hoor ons ons volksleiers dikwels die woorde gebruik dat God ons hier aan die Suidpunt van Afrika geplant het om die Evangelie aan die Heidene te bring en dat ons 'n goddelike roeping het. Ons sien dus: Die geskiedenisbeskouing van die Afrikaner is bepaal deur die Ou Testamentiese visie op die verlede van die volk van Israel. Predikante en geestelike leiers het dit veral i.v.m. Geloftedag diep in die harte tuisgebring.

Maar ek het lank uitgewei oor die roepingsidee. Daar is nog 'n element wat hier genoem kan word en dit is die Afrikaanse nasionalisme. Diep agter die geskiedbeskouing van die Afrikaner sit die nasionale gedagte. Die verlede is die bron wat die wese van die Afrikaanse volk geopenbaar het. Die beste wat in hom is, is in die verlede te vinde. Daarin is voorbeelde van staal, van mannemoed, heldedade en vryheidsliefde. Die geskiedenis het die karakter en die gees van die volk aan die lig gebring. Daarin is lering en rigting te soek. Sy hoogste nasionale waardes het daarin uitdrukking gevind. Daarom dat die Groot Trek en die Tweede Vryheids oorlog die twee pole geword het waaromheen sy geskiedsbeeld sou wentel. Wat vóór die Trek en ná die Driejarige oorlog gekom het staan nie baie helder in sy gees nie. $E n$ 'n mens kan raai waarom.

Samevattend kan 'n mens sê dat die Afrikaner homself in die geskiedenis gesien het as deur God hier in die land gebring en dat hy van God 'n bepaalde roeping en opdrag gekry het. Hy sien die roeping as die vestiging van die blanke, Christelike beskawing onder die Heidene en hy self is gelouter deur die Brit waardeur die beste van sy nasionale waardes in die geskiedenis, d.j. veral in die Groot Trek en die Tweede Vryheidsoorlog uitdrukking gevind het. En nou dat die wêreld één geword het 
en ons met die buitewêreld i.v.m. kleursake in beroering gekom het? Nou hoor ons dikwels die gedagte dat God die Afrikanervolk as „voorbeeld vir die wêreld" wil stel in die skepping van 'n regverdige en vreedsame samelewing uit verskillende elemente. Ook is die gedagte gehoor dat God in die verlede gelei het en nooit sal toelaat dat Sy volk in die stroom van gebeurtenisse sal vernietig word nie. Die beskouing wat in die 19de eeu ontwikkel het, word vandag dus aan moderne omstandighede aangepas. Dit is egter nie die opvatting van alle Afrikaners nie. Dit toon dat die 19de eeuse opvatting beperk was tot op die Afrikanervolk alleen. Die konfrontasie met nuwe omstandighede verg 'n nuwe aanpassing. Dis genoeg om hier te sê dat die geskiedbeskouing van die Afrikaner bepaal is deur godsdienstige en nasionale waar$\left.\operatorname{des}^{2}\right)$.

\section{F, A. VAN JAARSVELD.}

1) $\mathrm{Vir}$ besonderhede oor die Afrikaner se houding t.o.v. sy verlede vgl. my artikel in Hertzog-Annale, Des. 1957, Die Afrikaanssprekende en sy Geskiedenis (bls. 70-113); Standpunte nr. 10 (nuwe reeks), Die Ontstaan van die Afrikaanse Geskiedskrywing (bls. 42-53) en my Ontwaking van die Afrikaanse Nasionale Bewussyn waarin baie oor die geskiedenis gesê word. In Die Huisgenoot van 13 Desember 1957 is 'n artikel oor die geskiedenisbeskouing van pres. Kruger nl. „'n Volk se gedrag bepaal sy Verlede". 